\begin{tabular}{ccc|c|}
\hline JOURNAL PHYSICAL & HEALTH RECREATION \\
\hline & Holume 1 Nomor 1 ; November 2020 \\
\hline
\end{tabular}

\title{
STUDY OF BASIC TECHNIQUE SKILLS FOR PLAYING FUTSAL FOR FUTSAL EXTRACURRICULAR PARTICIPANTS IN SMA NEGERI 2 LUBUK PAKAM IN 2020
}

\author{
KAJIAN TINGKAT KETERAMPILAN TEKNIK DASAR BERMAIN \\ FUTSAL PESERTA EKSTRAKURIKULER FUTSAL SMA NEGERI 2 \\ LUBUK PAKAM TAHUN 2020
}

\author{
Togar Togatorop ${ }^{1}$, Dicky Hendrawan ${ }^{2}$ \\ Sekolah Tinggi Olahraga dan Kesehatan Bina Guna \\ Jl. Alumunium Raya, Sumatera Utara, 20241, Indonesia
}

\begin{abstract}
ABSTRAK
Penelitian ini bertujuan untk mengetahui Tingkat Keterampilan Teknik Dasar Bermain Futsal Peserta Ekstrakurikuler Futsal SMA Negeri 2 Lubuk Pakam Tahun 2020. Subjek dalam penelitian ini adalah siswa peserta kegiatan ekstrakurikuler futsal di sekolah SMA Negeri 2 Lubuk Pakam yang jumlah pemain 20 orang.Desain pada penelitian ini adalah menggunakan pendekatan studi kasus dengan survei jurnal-jurnal ilmiah yang telah terakreditasi. Kajian penelitian ini merupakan kajian kualitatif dengan menganalisis kajian keterampilan tehnik dasar futsal yang dihubungkan dengan kegiatan ekstrakurikuler di sekolah.Hasil analisis menunjukkan bahwa dalam upaya meningkatkan perkembangan kualitas dalam pendidikan jasmani, olahraga dan kesehatan dibutuhkan instrumen yang bisa mengukur kemampuan seseorang dalam melakukan olahraga permainan futsal. Adapun teknik dalam bermain futsal yaitu: teknik dasar mengumpan (passing), teknik dasar menahan bola (stopping), teknik dasar mengumpan lambung (chipping) tehnik dasar menggiring bola (dribbling), teknik dasar menembak bola ke sasaran (shooting), menyundul bola (heading), tehnik tendangan ke dalam serta tehnik penjaga gawang.Melalui kegiatan ektrakurikuler futsal juga dapat meningkatkan kebugaran jasmani siswa, serta dapat meningkatkan prestasi dalam olahraga seperti; siswa dapat mengikuti kejuaraan antar pelajar dan kejuaraan daerah. Dengan dilaksanakannya program kegiatan ekstrakurikuler futsal dengan baik dan terencana diharapkan terjadinyapeningkatan kemampuan dalam menguasai teknik dasar bermain futsal para siswa. Berdasarkan penjelasan di atas maka dapat di simpulkan bahwa dalam meningkatkan keterampilan tehnik dasar futsal pada para siswa peserta kegiatan ekstrakurikuler futsa, perlu diterapkan beberapa langkah yakni:1) Pembina kegiatan ekstrakurikuler futsal terlebih dahulu harus mengetahui tingkat keterampilan dasar siswa dalam menguasai tehnik dasar futsal baik itu dalam bentuk tes kemampuan dasar maupun game. 2)Sarana dalam pelaksanaan kegiatan ekstrakurikuler futsal harus lebih ditingkatkan baik berupa bola, cone dan kelengkapan lainnya.3) Pembina kegiatan ekstrakurikuler futsal harus lebih meningkatkan keterampilan siswa dalam bentuk latihan yang terpadu dan mengikuti pertandingan atau even kejuaraan agar dapat mengetahui kemampuan para siswanya.
\end{abstract}

\section{Kata kunci: Futsal, Ekstrakulikuler}




\section{ABSTRACT}

This study aims to determine the level of basic technical skills for playing Futsal for Futsal Extracurricular Participants at SMA Negeri 2 Lubuk Pakam in 2020. The subjects in this study were students participating in futsal extracurricular activities at SMA Negeri 2 Lubuk Pakam with 20 players.The design in this study is to use a case study approach with a survey of accredited scientific journals. This research study is a qualitative study by analyzing the study of basic futsal techniques skills associated with extracurricular activities in schools.

The results of the analysis show that in an effort to improve the quality development in physical education, sports and health, an instrument that can measure a person's ability to play futsal is needed. The techniques in playing futsal are: basic techniques of passing, basic techniques of holding the ball (stopping), basic techniques of chipping, basic techniques of dribbling (dribbling), basic techniques of shooting the ball at the target (shooting), heading the ball ( heading), inward kick techniques and goalkeeper techniques. Through extracurricular activities, futsal can also improve students' physical fitness, and can improve performance in sports such as; students can take part in inter-student championships and regional championships. With the implementation of the futsal extracurricular activity program properly and planned, it is hoped that an increase in the ability to master the basic techniques of playing futsal for students.Based on the explanation above, it can be concluded that in improving the basic futsal technical skills of students participating in futsa extracurricular activities, several steps need to be applied, namely:1) The coach of futsal extracurricular activities must first know the level of basic skills of students in mastering basic futsal techniques both in the form of basic ability tests and games.2) The facilities in implementing futsal extracurricular activities must be improved in the form of balls, cones and other equipment.3) The coach of futsal extracurricular activities must further improve student skills in the form of integrated training and participate in competitions or championship events so that they can find out the abilities of their students.

Keywords: futsal, ekstraculikuler

\section{PENDAHULUAN}

Di era milenial ini tentu pendidikan menjadi salah satu hal yang sangat penting demi kemajuan suatu negara, terutama di Indonesia. Tidak dapat dipungkiri bahwa pendidikan di negara Indonesia ini sekarang tertinggal dengan negaranegara lain. Kemajuan iptek dan terbukanya dunia luar membuat persaingan di dunia pendidikan semakin luas. Permasalahan globalisasi dalam bidang pendidikan terutama menyangkut output pendidikan, seperti diketahui di era globalisasi ini telah terjadi pergeseran paradigma tentang keunggulan suatu negara, dari keunggulan komparatif yang bertumpu pada kekayaan sumber daya alam kepada keunggulan kompetitif yang bertumpu pada pemilikan sumber daya manusia yang berkualitas.

Dengan pendidikan yang semakin maju diharapkan dapat mengangkat kemajuan suatu negara. Sebuah negara tidak hanya di tuntut oleh sebuah perekonomian yang maju tetapi pemerataan di sektor pendidikan sangat diperlukan. Pendidikan jasmani merupakan salah satu komponen penting dari pendidikan secara keseluruan. Hal ini disebabkan pendidikan jasmani mempunyai tujuan yang searah dengan tujuan pendidikan yaitu untuk membantu individu-individu mencapai pertumbuhan dan perkembangan optimal. Pembelajaran pendidikan jasmani sudah seharusnya diberikan pada satuan tingkat sekolah mulai dari sekolah dasar, sekolah menengah pertama, hingga sekolah menengah atas. Melalui pembelajaran pendidikan jasmani olahraga dan kesehatan ini siswa di harapkan mampu mencapai tujuan maksimal.

Pembelajaran itu diarahkan untuk membina pertumbuhan fisik dan pengembangan psikis yang lebih baik sekaligus membentuk pola hidup sehat sepanjang hayat, salah satunya dengan menanamkan pada siswa untuk hidup sehat melalui aktivitas jasmani dan olahraga. Salah satu tempat dimana 
siswa dapat melakukan aktivitas jasmaninya, tempat siswa belajar, mengembangkan minat dan bakat pada bidang olahraga adalah dengan melakukan kegiatan ekstrakurikuler khususnya dalam bidang olahraga. Kegiatan ekstrakurikuler olahraga adalah salah satu wadah pembinaan di sekolah yang memiliki tujuan dalam mengembangkan minat dan bakat siswa salah satunya di bidang olahraga.

Ekstrakurikuler olahraga itu sendiri merupakan kegiatan olahraga yang dilaksanakan pada luar jam pelajaran tatap muka di sekolah atau di luar sekolah yang bertujuan untuk memperluas wawasan, kemampuan, peningkatan dan penerapan nilai pengetahuan serta kemampuan berolahraga. Selain sebagai wadah atau tempat, kegiatan ekstrakurikuler olahraga juga diharapkan akan dapat meningkatkan kebugaran jasmani siswa sehingga siswa selalu dalam keadaan bugar dan bersemangat serta aktif dalam setiap mengikuti proses pembelajaran di sekolah. Dalam keadaan bugar maka proses pembelajaran yang berlangsung dapat tercapai dengan baik dan sesuai tujuan pembelajaran yang di harapkan.

SMA Negeri 2 Lubuk Pakam salah satu sekolah yang terletak di Kecamatan Lubuk Pakam, Kabupaten Deli Serdang, yang merupakan salah satu dari sekian institusi pendidikan ada di kabupaten Deli Serdang yang menyelenggarakan kegiatan ektrakurikuler, pengembangan potensi siswa selain akademik dikembangkan pula potensi siswa dari segi non-akademik. Beberapa kegiatan Ekstrakurikuler dibentuk untuk menampung berbagai macam potensi siswa-siwi SMA Negeri 2 Lubuk Pakam.

Kegiatan ekstrakurikuler di SMA Negeri 2 Lubuk Pakam yakni pramuka dan cabang olahraga pilihan yakni futsal, badminton, bola basket dan bola voli. Sekolah memberikan pilihan kepada para siswanya untuk dapat mengikuti kegiatan ekstrakurikuler yang sesuai dengan minat dan bakat dari masing-masing siswanya.
Permainan futsal dapat berlangsung lancar, teratur dan menarik apabila pemain menguasai berbagai unsur-unsur dalam permainan futsal, salah satunya adalah penguasaan teknik dasar. Teknik dasar yang harus dikuasai oleh pemain futsal adalah dribbling, shooting, control dan passing. Namun dilihat dari latihan bermain kegiatan ekstrakurikueler futsal di SMA Negeri 2 Lubuk Pakam yang dilakukan beberapa siswa masih mempunyai kendala untuk teknik dasar terutama passing dan shootingnya. Passing tujuannya untuk memberikan atau mengalirkan bola kepada teman. Passing yang baik dan benar sangat dibutuhkan dalam bermain futsal, karena dengan menguasai teknik ini maka akan mempermudah mengalirkan ataupun menghubungkan bola antar pemain dalam sebuah permainan futsal. Untuk penguasaan passing, diperlukan penguasaan gerakan sehingga sasaran yang diinginkan tercapai.

Berdasarkan survei pelaksanaan ekstrakurikuler futsal di SMA Negeri 2 Lubuk Pakam, saat melakukan latihan bermain, masih banyak siswa yang melakukan passing dengan menendang bola terlalu keras atau pun terlalu lemah, sehingga hasil yang didapat tidak sesuai arah yang diinginkan, kesalahan seperti itu memudahkankan lawan untuk merebut bola, yang mengakibatkan lawan mudah untuk mencetak gol.

Permasalahan yang lain untuk kebanyakan siswa adalah tehnik shooting. Shooting sangat penting dalam permainan futsal karena tujuan utamanya untuk menciptakan gol. Pemain yang memiliki shooting yang baik dan akurat akan mudah untuk menciptakan gol ketika mendapatkan setiap peluang yang ada. Shooting merupakan cara untuk menciptakan gol, ini disebabkan seluruh pemain memiliki kesempatan untuk menciptakan gol dan mengembangkan permainan atau pertandingan. Permasalahan yang sering dihadapi oleh siswa untuk shooting adalah kekuatan kaki kanan dan kaki kiri pemain ketika menendang bola masih lemah 
sehingga tendangan yang dihasilkan tidak tepat sasaran dan tidak terarah.

Ada beberapa pemain yang mempunyai kekuatan yang sudah cukup kuat tapi masih kurang akurat dalam menghasilkan gol. Hal ini dapat dilihat pada saat pemain melakukan latihan menembak ke arah gawang, dari 20 pemain yang melakukan shooting bola, hanya 9 pemain yang menghasilkan gol.

Selain itu pelatih juga belum pernah melaksanakan tes keterampilan dasar bermain futsal para pemainnya. Kegiatan ekstrakurikuler futsal terkesan hanya menjalankan kegiatan ekstrakurikuler saja tanpa mempunyai tujuan pencapaian prestasi. Dengan dilaksanakannya tes keterampilan dasar bermain futsal akan diketahui kelebihan dan kelemahan tehnik dasar yang dimiliki oleh para pemain, sehingga dalam pelaksanaan latihan dapat menyusun program latihan yang lebih baik dan terarah

\section{METODE PENELITIAN}

Desain pada penelitian ini adalah menggunakan pendekatan studi kasus dengan survei jurnal-jurnal ilmiah yang telah terakreditasi. Kajian penelitian ini merupakan kajian kualitatif dengan menganalisis kajian keterampilan tehnik dasar futsal yang dihubungkan dengan kegiatan ekstrakurikuler di sekolah.

Tahapan yang akan dilaksanakan dalam penelitian ini terdiri dari: 1) pengumpulan data terkait kajian-kajian yang terdapat pada jurnal penelitian yang meliputi "Keterampilan Tehnik Dasar Futsal" dan "Kegiatan Ekstrakurikuler di sekolah"; 2) melakukan analisis terhadap pola pelaksanaan kegiatan belajar; 3) melakukan perbandingan terkait pelaksanaan pembelajaran; dan 4) menemukan kesimpulan dan saran dari studi analisis.

\section{HASIL DAN PEMBAHASAN}

Penelitian yang dilaksanakan pada saat mewabahnya pandemi Corona Virus Desease 2019 (Covid-19) dilaksanakan dengan kajian analisis yang berkaitan dengan keterampilan tehnik dasar olahraga pada kegiatan ekstrakurikuler di sekolah pada tingkat Sekolah Menengah Atas (SMA). Data penelitian diperoleh melalui kajian analisis secara mendalam pada 3 jurnal nasional tentang keterampilan tehnik dasar dan 3 jurnal nasional tentang kegiatan ekstrakurikuler di sekolah.

Tujuan penelitian ini secara umum untuk mengungkapkan tingkat validitas dan reliabilitas tes keterampilan olahraga futsal dikalangan anak-anak sampai dewasa. Secara khusus penelitian ini bertujuan untuk mengungkapkan tingkat validitas dan reliabilitas tes keterampilan olahraga futsal siswa SMA dan sederajat se-Tasikmalaya. Objek penelitian ini adalah pengujian tingkat validitas dan reliabilitas instrumen keterampilan olahraga futsal. Penelitian ini dilaksanakan pada pemain futsal SMA/SMK/MA dan sederajat Kota Tasikmalaya di Sekolah-sekolah yang mempunyai sarana lapang futsal. Pada penelitian yang penyusun lakukan ini, penulis menggunakan metode penelitian dan pengembangan untuk menghasilkan produk tertentu, dan menguji keefektifan 
produk tersebut untuk mencapai tujuan (Sangadji dan Sopiah, 2010:103). Tujuan penelitian ini adalah membuat instrumen tes untuk olahraga futsal. Teknik pengumpulan data dilakukan melalui 3 instrumen tes yang akan di uji tingkat validitas dan reliabilitasnya. (1) Tes menyepak dan mengontrol bola, (2) Tes menggiring bola, (3) Tes menendang bola ke gawang. Pada penelitian, peneliti menggunakan metode penelitian dan pengembangan untuk menghasilkan produk tertentu, dan menguji keefektifan produk tersebut untuk mencapai tujuan (fungsi validasi). Sampel yang diambil dengan cara pursfosif sampling karena ada beberapa kriteria yang ditentukan yakni, sekolah yang sering mengikuti even-even dan masuk dalam perempat final baik lokal maupun daerah.

Hasil penelitiannya menunjukkan tingkat reliabelitas yang masih rendah tetapi tingkat validitas yang sudah rata-rata tinggi. Perlu di adakan kembali revisi instrumen untuk menghasilkan tes yang lebih baik lagi dengan minimal kategori sedang dalam hal reliabilitas dan validitasnya. Reliabilitas tes keterampilan futsal belum terbukti memiliki tingkat keajegan yang tinggi, sehingga tes ini perlu dievaluasi dan dianalisis kembali untuk mencapai tingkat keajegan minimal kategori sedang. Validitas tes keterampilan futsal sudah terbukti memiliki tingkat kesahihan yang rata-rata tinggi, sehingga tes ini bisa digunakan untuk dimanfaatkan oleh masyarakat. Namun tingkat validitas tersebut tidak didukung oleh nilai reliabilitas, sehingga tes tersebut perlu adanya analisis kembali untuk mendapatkan syarat menyusun suatu tes minimal yaitu terbukti valid dan reliabel.

Bagi para peneliti diharapkan agar lebih memperhatikan objek dan sarana penelitian dalam melakukan uji coba suatu instrumen tes, karena tingkat kemampuan setiap sampel dan keterbatasan sarana akan sangat mempengaruhi hasil penelitian.

Dari hasil penelitian yang telah dilakukan, dapat disimpulkan sebagai berikut; a) Ada peningkatan keterampilan teknik dasar passing dari sebelum menggunakan metode rondo dan sesudah menggunakan permainan metode rondo pada siklus I, yaitu terbukti ada peningkatan dari $50 \%$ dari 20 mahasiswa yang mendapat nilai tuntas dari jumlah 40 mahasiswa berdasarkan rincian persentase nilai (A) 12 orang, (B) 8 orang, (C) 20 orang dengan menggunakan metode rondo dengan 1 orang yang menjadi penjaga, b) Pada siklus II ada peningkatan keterampilan passing dalam permainan futsal metode rondo dengan 2 siswa yang menjadi penjaga. Terbukti dari hasil penelitian dengan hasil peningkatan $65 \%$ tuntas dari siklus I yang hanya 50\% tuntas dari 40 siswa dengan rincian nilai (A) 16 orang, (B) 9 orang, (C) 15 orang. Tampak peningkatan dari siklus I yaitu $15 \%$ 
peningkatan dengan ketuntasan dari 20 mahasiswa menjadi 26 mahasiswa yang tuntas dalam pembelajaran Futsal.

Ditinjau dari proses pelaksanaan program pengembangan diri melalui kegiatan ektrakurikuler futsal di sekolah SMA Negeri 2 Lubuk Pakam, seharusnya bisa berjalan dengan baik karena futsal adalah cabang olahraga yang menarik. Melalui kegiatan ektrakurikuler futsal juga dapat meningkatkan kebugaran jasmani siswa, serta dapat meningkatkan prestasi dalam olahraga seperti; siswa dapat mengikuti kejuaraan antar pelajar dan kejuaraan daerah. Dengan dilaksanakannya program kegiatan ekstrakurikuler futsal dengan baik dan terencana diharapkan terjadinya peningkatan kemampuan dalam menguasai teknik dasar bermain futsal para siswa.

Berdasarkan penjelasan di atas maka dapat di simpulkan bahwa dalam meningkatkan keterampilan tehnik dasar futsal pada para siswa peserta kegiatan ekstrakurikuler futsal, perlu diterapkan beberapa langkah yakni:

1) Pembina kegiatan ekstrakurikuler futsal terlebih dahulu harus mengetahui tingkat keterampilan dasar siswa dalam menguasai tehnik dasar futsal baik itu dalam bentuk tes kemampuan dasar maupun game.

2) Sarana dalam pelaksanaan kegiatan ekstrakurikuler futsal harus lebih ditingkatkan baik berupa bola, cone dan kelengkapan lainnya.

3) Pembina kegiatan ekstrakurikuler futsal harus lebih meningkatkan keterampilan siswa dalam bentuk latihan yang terpadu dan mengikuti pertandingan atau even kejuaraan agar dapat mengetahui kemampuan para siswanya.

Konsep pelaksanaan tes dan game seperti yang telah dijelaskan diatas, maka akan dapat mengetahui dan menyusun rencana serta program dalam upaya peningkatan kemampuan teknik dasar bermain futsal yang dilakukan secara terprogram.

\section{KESIMPULAN}

Penelitian analisis kajian tentang keterampilan teknik dasar bermain futsal dan kegiatan ekstrakurikuler olahraga di sekolah pada masa Pendemi Corona Virus Desease-19 dilakukan dengan studi pustaka jurnal nasional. Kajian dilakukan dengan menemukan karakteristik keterampilan teknik dasar bermain futsal pada para peserta kegiatan ekstrakurikuler futsal di sekolah SMA Negeri 2 Lubuk Pakam. Kajian keterampilan teknik dasar bermain futsal memiliki karakteristik untuk meningkatkan kemampuan teknik dasar mengumpan (passing), teknik dasar menahan bola (stopping), teknik dasar mengumpan lambung (chipping) tehnik dasar menggiring bola (dribbling), teknik dasar menembak bola ke sasaran (shooting), menyundul bola (heading), tehnik tendangan ke dalam serta tehnik 
penjaga gawang.

Hasil analisis kajian dapat direkomendasikan pada SMA Negeri 2 Lubuk Pakam mengenai kegiatan ekstrakurikuler futsal di sekolah tersebut. Diharapkan dengan dilaksanakannya kegiatan ekstrakurikuler futsal diharapkan ketersediaan waktu latihan yang cukup, dukungan sarana dan prasarana dari pihak sekolah serta motivasi dari pelatih diharapkan dapat meningkatkan keterampilan tehnik dasar bermain futsal dari siswa peserta kegiatan ekstrakurikuler futsal serta dapat meraih prestasi dalam berbagai even atau pertandingan yang diikuti.

\section{DAFTAR PUSTAKA}

Agus Salim dan Yanuar Kiram. (2020). Pelaksanaan Kegiatan Ekstrakurikuler Sepakbola Sekolah Menengah Pertama (SMP) Negeri 2 Rambatan. Jurnal Patriot, Volume 2 Nomor 1. Padang

Abdul Narlan, Dicky Tri Juniar dan Haikal Millah (2017). Pengembangan Instrumen Keterampilan Olahraga Futsal. Jurnal Siliwangi Seri Pendidikan, Volume 3 Nomor 2.

John D. Tenang. (2008). Mahir Bermain Futsal. Bandung: DAR Mizan.

Sugiyono. (2007). Metode Penelitian Kuantitatif, Kualitatif dan R \&D. Bandung: Alfabeta.

Sugiyono. (2012). "Metode Penelitian Kuantitatif, Kualitatif, dan Kombinasi (Mixed Methods)." Bandung: Alfabeta. 